\title{
JUURNAL.RU
}

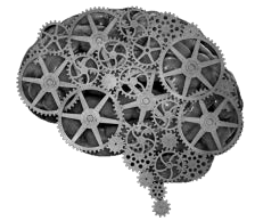

COMPANY GROUP "INTELLEKT"

Косырева М.С.

Сибирский институт управления - филиал Российской академии народного хозяйства и государственной службы при Президенте Российской Федерации

Новосибирск, Россия

doi: 10.18411/lj2016-7-1-11

idsp 000001: lj2016-16-1-11

\section{Морфологические признаки интернациональной лексики в русском и английском языках}

Критерии принадлежности слов того или иного языка к интернациональному лексическому пласту остаются неизменными на протяжении последних десятилетий. Традиционно наиболее существенным для «узнавания» интернациональных слов считалось наличие регулярных соответствий и сходства звуков в основе или корне[1]. Расхождения и несопоставимость отдельных звуков часто компенсируются, так как слово воспринимается не как набор звуков, а как единое целое, причем различительная сила тем больше переходит от качества отдельных звуков к их количеству, чем больше их количество в слове. Однако наиболее показательно, прежде всего в лексикографическом плане, сходство и расхождение в письменной речи.

Расхождения письменных форм интернационализмов в русском, английском, немецком и французском языках связаны не только с расхождениями передаваемых на письме звуковых оболочек слов, но и разными принципами передачи сходных звуков. Сказываются, в частности, особенности написания слов иностранного происхождения, усложняющие орфографические системы языков. Тем не менее, подавляющее большинство интернационализмов в письменной форме достаточно легко отождествляется в разных языках 
благодаря комплексности их восприятия и достаточности узнавания лишь общего контура, а не всех деталей слова. Она реализуется в полной мере уже на морфологическом уровне.

Возможность закономерных соответствий и сходства интернациональных слов в устной или письменной форме нередко связана с существованием определенного параллелизма в морфологических структурах этих слов. Параллелизм обычно бывает лишь частичным, так как в каждом языке структура интернационализмов может иметь особенности независимо от того, сочетают ли слова интернациональные и специфические элементы или полностью состоят из интернациональных морфем. Именно на уровне морфемы принадлежность слова к интернационализмам становится более или менее очевидна, так как морфема минимальная значимая единица языка.

Исторически расхождения объясняются неизбежной спецификой словообразования в каждом языке, разной степенью точности передачи прототипов интернационализмов (если таковые имелись), разными стереотипами словообразовательного оформления заимствуемых слов и образования производных от них.

Ни у кого не вызывает сомнений существование соответствий в словах с производной основой. И здесь они далеко не всегда означают тождество: последовательности морфем в слове может соответствовать в слове другого языка сходная по звучанию (написанию) нечленимая часть слова. Кроме того, в производной основе могут встречаться неинтернациональные элементы (обязательна интернациональность только корня и префиксов). Наличие в слове одного-двух специфических суффиксов не мешает ему функционировать как интернационализму, если эти специфические суффиксы регулярно соотносятся с суффиксами других языков в определенном классе слов.

Специфика суффиксального оформления неодинакова в трех основных частях речи, к которым принадлежит подавляющее большинство 
интернационализмов русского и английского языков: в существительных она может отсутствовать, но она неизбежна в прилагательных и глаголах.

Картина английского языка осложняется словообразованием по конверсии в многочисленных случаях типа absolute «абсолют»-absolute «абсолютный», asphalt «асфальт» — asphalt «асфальтировать» или более редких типа code «код» — code «кодовый»—code «кодировать». В русском языке в первую очередь прилагательным и глаголам и производным от них свойственно сочетание суффиксов со своеобразными интерфиксами, лишенными самостоятельного значения и отражающими ориентацию на звучание аналогичных слов французского, немецкого и английского языков. Так возникают элементы, представляющие собой сплав русского суффикса с иноязычным, например: альн, -ональн, -абельн, -озн, -арн, -йен, -(и)онни пр.

Соответствия в структурах производных слов касаются, в частности, интернациональных суффиксов при интернациональных же основах. Таковы в пределах имен существительных суффиксы: -ист- -ist, - изм — -ism, -ация, яция(я) — -ation, -иция — -ition, -уци(я), юци(я) - -ution, -изаци(я) - -ization, -фикаци(я) — -fication, -енци(я) — -епсе, епсу и др.

Вероятность данных соответствий достаточно высока, хотя в каждом языке встречаются единичные и групповые отклонения.

Одним из проявлений перебоев в рядах морфемных соответствий является вариантность слов, распространенная среди интернационализмов в результате возможного заимствования сходных слов из разных источников, а также самостоятельного создания их по разным моделям. Она может характеризовать единичные слова (матрас-матрац, ноль - нуль, тоннель - туннель), что может охватывать группы однородных слов (типа русских прилагательных на ичный, -ический,глаголов на -изировать - -изовать и т. д.) или отражать территориальное варьирование языка (как aluminium — aluminum, candidature candidacy, telegraphist — telegrapher, где первые формы из британского, вторые из американского английского). 
Современное нивелирование ареалов интернационализмов благодаря метапространственной интернет-коммуникации приводит $\quad$ к появлению значительных групп структурно неоднородных интернациональных слов. Однако основная масса наиболее характерных интернационализмов отличается сходными в разных языках закономерностями в структурно-морфологическом и словообразовательном аспектах.

Наиболее распространены и относительно общепонятны в русском литературном языке основы агглютинативного типа классического и неоклассического происхождения, способные образовывать интернациональные сложные слова, сочетаясь друг с другом. Подобные слова (блоки слов) являются самыми явными и давно признанными интернационализмами языков Европы. Большинство таких блоков употребляется лишь препозитивно: напр., авто-, агро-, ангио-, антропо-, архео-, астро-, аэро-, баро-, библио-, био-, вибро-, видео-, гальвано-, гастро-, гекто-, гео-, гетеро-, гигро-, гидро-, гипо-, гисто-, еомо-, грави- графо-, демо-, деамато-, зоо-, -изо, иконо-, ионо-, историо, ихтио-, калори-, карбо-, кар- дио-, карто-, катодо-, кило-, крипто-, лакто-, лито-, магнето, макро-, мега-, мезо-, метро-, микро-, моно-, невро-, нео-, нитро- и т.П. Этот первый тип блоков особенно легко может быть пополнен новыми основами, главным образом из греческих корней с интерфиксом.

Блоки, употребляющиеся в постпозиции, образуют второй, ограниченный, но потенциально также открытый тип: -биоз, -бус, -гамия, -ген, -генез,- гнозия, гония, -грамма, -граф, -графия, -дром, -лит, -лог, -логия, -ман, -мания, -метр, метрия, морфизм, -навт, -навтика, -олеум(-оль), -пат, -патия, -патолог,- план, скоп, -скопия, -стат, -типия, -тон, -фаг, -фил, -филия, -фит, -фоб, -фобия, -фон, цид, -цит и т.п. У таких элементов отмечается тенденция к переходу в суффиксы.

Блоки препозитивного типа могут сочетаться как с постпозитивными блоками, так и с иными интернациональными основами. Их участие придает слову вид явного европеизма, не нуждающегося в переводе, а передаваемого 
простой перекодировкой, хотя такие слова не всегда получают интернациональное распространение.

Сравнительно широко понятны в литературном языке интернациональные префиксы: а-, анти-, архи-, вице-, гипер-, де-/дез-, дис-, квази-, контр-, пан-, прото-, псевдо-, ре-, супер-, транс-, ультра-, экс-, экстра- и др. Среди суффиксов интернациональных слов в русском языке преобладают интернациональные морфемы, правда, нередко непродуктивные, a иногда даже имеющие уникальный характерсуффиксоиды, например, -борд[2].

К суффиксам интернациональных существительных мужского рода со значением лица относятся -ал, -ан, -ант/ент, -ар, -арь, -атор/-итор, -ер, -ет, -ец, йот, -ик, -ист и пр., женского рода - -есс(а), -ис(а).

К суффиксам существительных мужского рода со значением предметности относятся: -ант/ент, -арий, -орий, -ат, -атор/-тор/-ор/-ёр/-ер, -ин, -uр, -ит, -ад, оид, -он, -трон и пр., женского рода: -ад(а), -и(я), -ур(а), -ерк(а). Вычленяется также ряд суффиксов существительных со значением отвлеченности: у существительных мужского рода: -аж, -ант, -оз/-ез, -изм, -итет, женского рода: иад(a), ур(а), -из(а), -иан(а), -ичность, -ик(а),-аци(я), -енци(я), -ость, ональность, -уальность.

К суффиксам интернациональных прилагательных в русском языке относятся: -абельн, -ск, часто в сочетаниях: -альн, -анск, -арн-(-ярн), -йен, ическ, -ационн, -иальн, -ионн, -истическ, -истск, -ичн, -озн, -оидальн, -оидн, ональн, -онн,-орн, -уальн, -урн, -ционн и др. В интернациональных глаголах встречаются суффиксы: -изирова, -изова, -ирова-, -ова-, (-ева), -фицирова, в наречиях суффиксы -и, -о в сочетаниях: -истически, -истеки-, -ически, -ично.

Лишь часть подобных суффиксов продуктивна в общелитературном языке. Таковы суффиксы существительных: -аж, -ант, -ат, -аци(я) (-яци(я)), -ор/-ёр, изм, -ик, -ист, -ит, -онер, -тор, (-атор, -итор), -ур(а), -фикаци(я) (-ификаци(я). Многие же суффиксы непродуктивны и вычленяются только в результате 
появления в языке значительных групп заимствований, относящихся к одинаковым словообразовательным рядам.

Большая степень сходства интернациональных слов именно в письменной, a не в устной форме является общим правилом[3]. Она в равной степени свойственна и интернационализмам русского и английского языков, хотя в первом орфографическое оформление международной лексики часто оказывается специфичным по сравнению со вторым. Исторически такое отклонение русских слов от аналогичных слов английского и других европейских языков объясняется тем, что русский язык обычно транскрибирует заимствуемые слова, тогда как в западноевропейских языках заимствуемые слова транслитерируются, что нередко ведет к их буквальному совпадению в ряде языков ввиду их графической близости. Эта ситуация только способствует расширению интернационального лексического пласта, что, кроме прочего, обеспечивает большую интенсивность межъязыкового взаимодействия. 


\section{Литература:}

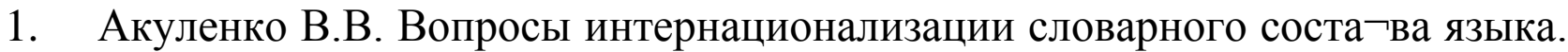
Харьков, 1972.

2. Богословская В.Р.

3. Косырева М.С. Глобализмы в русском языке. М., 2016. 